\title{
A tárgyválasztás és -használat sajátosságai óvodás és kisiskolás gyermekek körében
}

A modern pszichológia mentális reprezentációkban való fixálódása nem csupán eltereli a figyelmet a gyermeket körülvevó emberek.

tárgyhasználat során tanúsitott szerepéról, de maguknak a tárgyaknak a pszichológiai jelentóségét is lekicsinyli (Williams és Costall, 2000). Ezen materiális világ azonban számos információt hordoz számunkra kultúránkról és társadalmunk múködéséról. A tárgyak pedig mediátorként állnak, és támogatják a gyermekek

szocializációját. Azok rendelkezésre állása/elérhetósége, de a játékanyag ismerôssége, érdekessége egyaránt befolyásolják, hogy aktuálisan melyek kerülhetnek a gyermek figyelmi spektrumába, és nyerhetnek prioritâst.

$\mathrm{N}$ éhány korábbi vizsgálat játékok felkínálásával és azokról készült fotók bemutatása révén igyekezett közelebb kerülni a gyermekek tárgyválasztásának és -használatának jobb megértéséhez. Ezekben a munkákban azonban a hangsúly inkább a gyermekek által előnyben részesített játékkategóriák feltárásán volt, s a tárgyválasztás és -használat egyéb aspektusai - melyek a percepciót és a gyermeki kreativitást tekintenék - nem képezték a vizsgálatok tárgyát. Az elénk táruló élettelen környezet tárgyai azonban változatos formát ölthetnek, melyek sokoldalú tárgyhasználatra invitálják a cselekvő embert. Kutatásomban tehát óvodás és kisiskolás gyermekek tárgyválasztásáról és -használatáról kívántam információkat gyüjteni, összehasonlító jelleggel. A vizsgálatban mindkét korcsoportból 15-15 gyermek vett részt, az ingeranyagot a később (15 perc időtartamban) játéktárgyként is rendelkezésre bocsátott eszközökről készült képek, használatukat demonstráló videók és maguk az objektek szolgáltatták. A gyermekek kreativitásának mérésére egy további rövid feladat is szerepeltetve lett. A tesztfelvétel minden esetben egyéni formában zajlott, az eredmények rögzítése egy jelen kutatáshoz összeállított külön adatlapon és szempontsor alapján történt. Mindezek alapján elmondható, hogy (1) a vizsgálatba vont gyermekek tárgyválasztási preferenciája életkori és nemi különbségeket egyaránt igazolt, valamint (2) a konvencionális tárgyak rendszerint szívesebben lettek úgymond játékba vonva, mint ez a furcsa tárgyak tekintetében megnyilvánult. (3) A kreatívabb gyermekek inkább voltak nyitottak a számukra idegen objektek megismerésére, ahogyan a tárgyakkal folytatott manipuláció során azok sokoldalú felhasználásának lehetőségét is jobban felismerték. A tárgyválasztás és -használat fejlődésének átfogóbb megértése azonban további szisztematikus vizsgálatokat kíván. 


\section{Bevezetés}

A humán viselkedés megértésének előfeltétele és értelmezi kerete azon kontextus, amelyben az megnyilvánul. A jelentésadás forrásaként tehát mondhatjuk úgy is, hogy a kultúra áll. Bronfenbrenner (1977) a körülvevő világot mikro-, mezo-, exo- és makroszisztémára bontotta. A mikrorendszer a gyermek direkt környezetére utal, amely a materiális, a strukturált és az interperszonális környezetet egyaránt magában foglalja. A mezorendszer az életünk során mind táguló helyszínek és csoportok világát, az exorendszer a gyermekre direkt/indirekt hatást kifejtő társas világot, a makrorendszer pedig az adott kultúra gazdasági, szociális, politikai intézményrendszerét, valamint - tágabb értelembe véve - a szociális viselkedést meghatározó normákat és szabályokat jelenti (Kósa, 2005) (1. ábra).

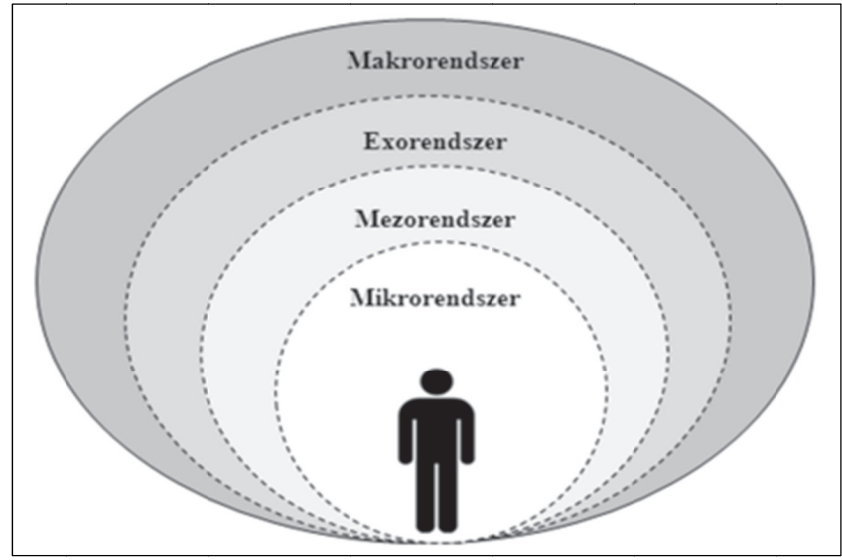

1. ábra. Az ember és környezete

A gyermek fejlődésének így eredője a környezet (Elkonyin, 1964), melynek komponensei a folyamatot felgyorsíthatják vagy lelassíthatják (Piaget, 1974). Emellett azonban fontos megjegyeznünk, hogy „a kultúra és a személyiség viszonyát a reciprocitás jellemzi: irányt szab minden egyes gyermek fejlődésének, és az individuumok aktivitása megváltoztatja a kultúra előzetes formáját" (Kósa, 2005. 66. o.). Az adott társadalom, kultúra által megkívánt és elvárt tudást, készségeket pedig szocializációnk folyamatában tesszük magunkévá.

\section{Az anticipatórikus (elővételezett) szocializáció}

A normák, készségek, konkrét szabályok és komplex vélekedésrendszerek elsajátítása - a kognitív-szociális tanuláselméleti perspektíva értelmében - direkt instrukciók, obszervációs (megfigyeléses) tanulás és formálás révén megy végbe (Kósa, 2005) (2. ábra). 


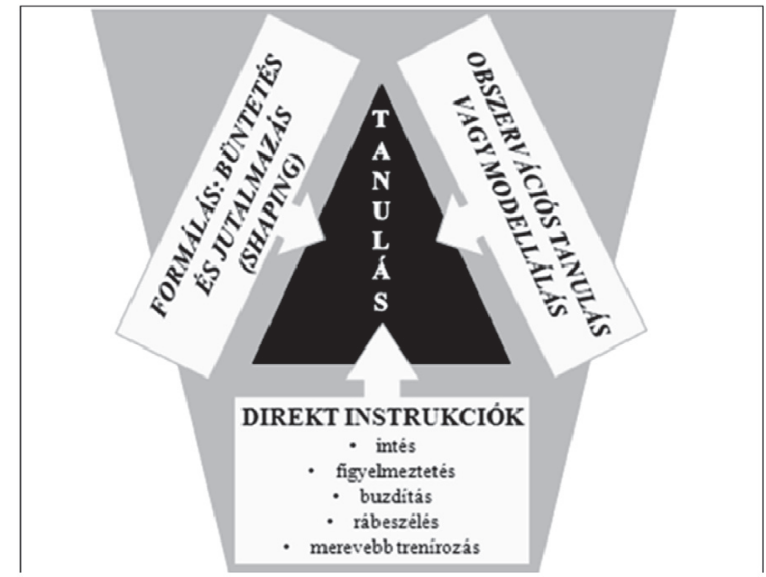

2. ábra. A tanulás háttértényezöi (Kósa, 2005. 88. o. nyomán)

A szocializáció azonban nem korlátozódik a valós helyzetekre és lehetőségekre. Arra speciális alkalmat kínál a játék, melynek során a gyermek a nappali ábrándozások, jövőbeli helyzetek és várható szerepek úgymond előrevételezésével (anticipálásával) próbálhatja ki magát, gyakorolhat (Kósa, 2005). A játék a gyermeki fejlődést számos aspektusból támogatja. Egyaránt fejleszti a kognitív, nyelvi, érzelmi képességeket és járul hozzá a társas fejlődéshez (Bergen, 2002; Fisher, 1992). Továbbá a gyermek által demonstrált ezen tevékenység a nevezett képességekre nézve prediktív funkcióval is bír (Pellegrini, 2006). A játék egyes képességterületekre vonatkozó, különböző életkorban betöltött szerepének különbségei azonban nem tisztázottak (Vandenberg, 1981). Egyes kutatók fokozott jelentőséget tulajdonítanak a „mintha játéknak” (Bergen, 2002; Stagnit$t i$ és Unsworth, 2000), mások szerint - kauzalitás helyett - inkább érdemes korrelációs összefüggésről szólni a játék és a fejlödés egyes aspektusainak változásait, viszonyát illetően (Lillard, Lerner, Hopkins, Dore, Smith és Palmquist, 2013).

A korai játékformák azonban kétségtelenül prioritást élveznek a későbbiekkel szemben, azok számára bázist nyújtanak, ezért nem megfelelö színvonaluk/sérülésük a gyermek további fejlődését, társas megnyilvánulásait és tanulási folyamatait komolyan befolyásolja (Bergen, 2002; Williams és Kendell-Scott, 2006). Így például autizmus spektrum zavarral élö gyermekeknél a „mintha játék” terén mutatott deficit (Lam és Yeung, 2012; Kékes Szabó és Szokolszky, 2013) kapcsolatba hozható a társas készségek problematikájával (Hobson, Hobson, Malik, Bargiota és Calo, 2012). A másik oldalról nézve: a (tárgyi) játék a gyermek kultúráról és társadalomról szerzett ismereteinek tükreként fogható fel, ami a benne végbemenő mentális folyamatokról vall (Bretherton, 1984; Rogers, Cook és Meryl, 2005).

\section{A tárgyhasználat alakulása gyermekkorban}

Környezetünket érzékszerveink összehangolt müködése révén térképezzük fel, amely folyamatban a vizuális információk befogadása (mintegy 80\%-ot adva) a legnagyobb arányban képviselt. Míg személyészleléskor hajlamosak vagyunk az illető egyed belső sajátosságaira nézve is következtetéseket levonni, addig a fizikai észlelés alkalmával a tárgyak felszíni tulajdonságait vesszük számba. Ez alapján pedig - ismeretlen tárgy esetében - következtetésekkel élünk annak elgondolt funkciójára vonatkozón. Az adott 
objektre jellemző szín, méret, forma és textúra ugyanis éppen úgy kitágíthatja, miként korlátozhatja a felhasználás lehetséges módjait (bottom-up folyamatok). Hasonlóképpen egy adott vagy hasonló tárggyal/tárgyakkal szerzett tapasztalataink, mint meglévő tudásunk, valamint aktuális szükségleteink és motivációink (top-down folyamatok) is hatással vannak magatartásunkra.

Logan, Schreiber, Lobo, Pritchard, George és Galloway (2015) alábbiakban bemutatott modellje jól szemlélteti a korai tanulás és fejlődés hátterében meghúzódó tényezőket és azok viszonyrendszerét (3. ábra).

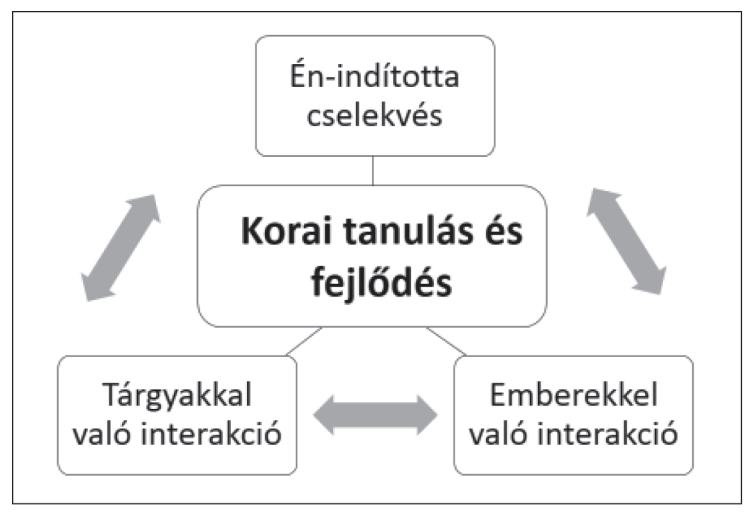

3. ábra. A korai tanulás és fejlödés háttértényezői (Logan és mtsai, 2015. 437. o.)

Az ábrán látható magatartásformák (én-indította cselekvés, tárgyakkal és emberekkel való interakció) gyakran együttesen fordulnak elö, s azok bármelyikének fejlesztése várhatóan a többi kategória vonatkozásában is szupportív hatást eredményez (Logan és mtsai, 2015).

De miként is definiálhatjuk magát a tárgyhasználatot? A témában megjelent tanulmányok szélesebb spektrumon kezelik a gyermeknek ezt a tevékenységét, ideértve egy adott objekt megérintését, birtokbavételét és a vele helyváltoztatás közben való manipulációt. A tárgyhasználat ilyenformán alapvetően a gyermek által mobilizálható darabokra korlátozódik. Kevés információval rendelkezünk viszont a tipikus fejlődésü gyermekek hétköznapi tárgyhasználatára nézve. Annyi bizonyos, hogy már a kisgyermekeknél is nagyszámú, heterogén és párhuzamos objekt bevonásával járó cselekvésformák (mozgás, játék, tárggyal végzett tevékenység) figyelhetőek meg (Logan és mtsai, 2015). A tárgyhasználatra vonatkozó szisztematikus vizsgálatok azonban hiányoznak a gyermekek fejlödésével összefüggésben végzett kutatások sorából (Pellegrini, 2016).

A gyermekek a számukra vonzó tárgyak megszerzésére vonatkozó igényüket 9-15 hónapos korukban már a gondozójukkal létesített szemkontaktus és nekik szóló mosoly által képesek „,megüzenni”. Ezen nonverbális jelek tehát az én-indította cselekvés jelzéseiként állnak (Messinger és Fogel, 2008). A tárgyak konvencionális használatának elsajátítása azután implicit módon - társas környezetünk, gondozóink mintáját követve - történik meg (Valsiner, 1987). Már egy hat hónapos gyermek is alapvető tudással rendelkezik a tárgyhasználatra vonatkozóan. Tisztában van azzal, hogy számos tárgy úgymond mire jó, és használatuk során milyen egyéb dolgokkal kerülhet az a mindennapokban kapcsolatba (pl. egy csészét a szánkhoz szoktunk emelni, amikor iszunk, vagy a telefonkagylót a fülünkhöz érintjük, hogy halljuk beszélgetőpartnerünk szavait). Később ezen asszociációs kapcsolatok előhívása mind rövidebb időt vesz igénybe. Vagyis, ha a 
gyermek látja, hogy egy csészéért nyúlunk, majd azt felemelve magunk felé közelítjük, akkor predikcióval él a tárgyhasználat célpontját illetően lásd az adott mozdulatsor záró momentumaként a szánkhoz fogjuk vinni a kis edényt, hogy jóízüen elfogyaszthassuk belöle a vágyott habos kávénkat (Hunnius és Bekkering, 2010). Míg egy kétéves gyermek leutánozza és alkalmazza a tárgyak konvencionális használatát, a hároméves gyermek immár tudását általánosítja, és másokkal szemben is elvárásokat támaszt a kapcsolódó információkra nézve. Ez utóbbinak pedig feltétele lehet a gyermek általánosabb perspektívában való gondolkodása és az elmeolvasási képességének fejlődése. Mire óvodás lesz a gyermek, már számos dolog konvencionális természetéröl, tárgyak közmegegyezésen alapuló felhasználási lehetőségéről szerez ismereteket. Mindebben a körülvevő felnőtt társadalom tudatos és következetes tárgyhasználata szolgálhat megbízható modellként a gyermeknek, aki érzékenyen fogja a környezetéből érkező jeleket, s azok nyomán alakítja magatartását. Figyelemre méltó, hogy a fejlődés folyamatában a gyermekek a körülvevő világ konvencionális „felhasználói” iránt mutatnak fokozott érdeklődést, azaz velük mint kompetens személyekkel szívesebben lépnek interakcióba. Hiszen őket a magukéhoz hasonló gondolatokkal és preferenciákkal rendelkezőként észlelik (Wohlgelernter, Diesendruck és Markson, 2010). Ez a stratégia egyúttal önnön cselekvésük, müködésük helyességének megerösítéseként is áll.

Bizonyos esetekben azonban nem konvencionális módon is cselekvésbe vihetünk egy-egy objektet. A tárgyhasználat ugyanis szoros kapcsolatban áll a játékra való képességgel, mely utóbbi az óvodáskorú gyermekek alaptevékenységeként fogható fel (Balogh, 1991). A „mintha játék” pedig, melyben - annak talán leginkább elfogadott felfogását alapul véve - egy adott tárgyat annak eredeti funkciójától eltérő módon, egy másikat helyettesítve használnak a gyermekek, talán a legismertebb formája ennek a kreatív megnyilvánulásnak.

\section{Kreativitás és fejlődés}

„A kreativitás egy olyan pszichológiai tevékenység, amely összefüggések felfedezéséről és produktumok létrehozásáról szól. Ezek pedig mindig újszerüek, eredetiek és mások számára haszonnal bírnak" (Köváry, 2015. https://www.youtube.com/ watch? $v=k g D 5 w H p y b-g)$. Az emberi elme egyik legfőbb erőforrásáról van szó, ami a kulturális és technikai evolúcióban komoly szereppel bírt (Kerr, 2009). Hasonlóképpen az ember megküzdö képességének és alkalmazkodásának egyik fontos összetevője (Russ, 1998), ezért a kognitív egészség alapköveként tekinthetö. Hatással van az egyén percepciójára, kompetenciaérzetére és mindennapi életvitelére (Fischer és Specht, 1999). A tehetséges gyermekek ismérveinek sorában is gyakran megtaláljuk a kreativitást és produktív gondolkodást (Czeizel, 1997; Renzulli, 2002; Brown, Renzulli, Gubbins, Siegle, Zhang és Chen,

S hogy miként is viszonyul egymáshoz a kreativitás és a gyermeki játék? Az ember játékos attitúdje elengedhetetlen feltétele mindennemú kreatív megnyilvánulásnak. A gyermek „mintha játéka” a divergens gondolkodással és problémamegoldással (kognitív aspektus), valamint a történetmeséléssel, érzelemkifejezéssel és -szabályozással (affektív vonatkozás) összefüggést mutat. A kreatív játék ugyanis természetes közegét adja a pozitiv és negativ érzelmekkel való találkozásnak (Fuchs, Komar és Porter, 2007), miként abban a gyermeki indulatok is megmutatkozhatnak (Russ és Schafer, 2006). 


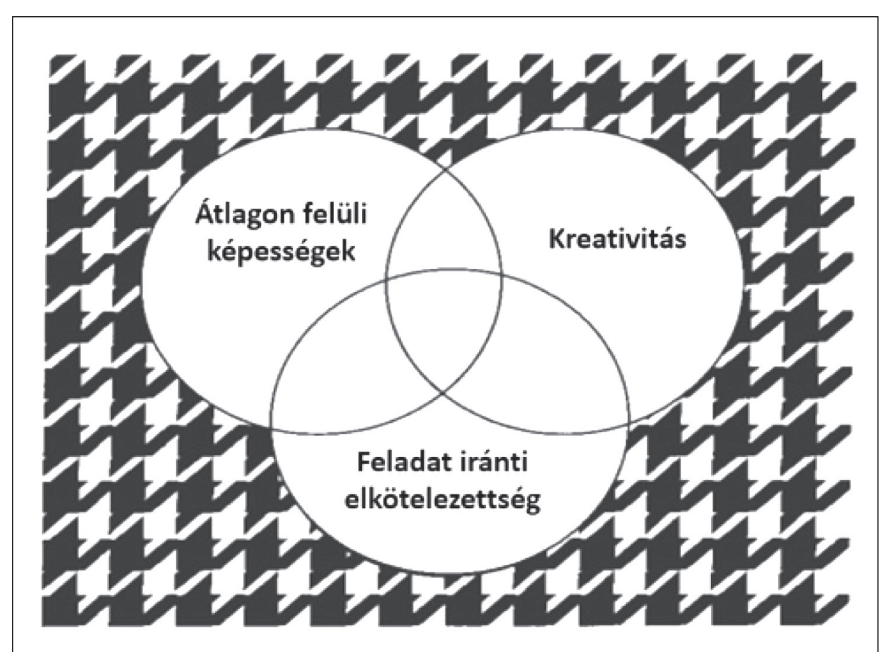

4. ábra. A tehetség 3-gyürüs koncepciója az annak bázisát képezö személy-környezet interakciót jelképezö rácsos mezövel (Renzulli, 2002, 71. o.)

2005) (4. ábra), vagyis pedagógiai és pszichológiai vonatkozásai egyaránt vannak ennek a humán sajátosságnak.

S hogy miként is viszonyul egymáshoz a kreativitás és a gyermeki játék? Az ember játékos attitüdje elengedhetetlen feltétele mindennemü kreatív megnyilvánulásnak. A gyermek ,mintha játéka” a divergens gondolkodással és problémamegoldással (kognitív aspektus), valamint a történetmeséléssel, érzelemkifejezéssel és -szabályozással (affektív vonatkozás) összefüggést mutat. A kreatív játék ugyanis természetes közegét adja a pozitív és negatív érzelmekkel való találkozásnak (Fuchs, Komar és Porter, 2007), miként abban a gyermeki indulatok is megmutatkozhatnak (Russ és Schafer, 2006). Mindazonáltal a végrehajtó funkciókat illetően hasonló együttjárás idáig nem került igazolásra (Hoffmann és Russ, 2012; Wright és Diener, 2012).

A gyermekkor játékélményei és érzelmi folyamatai továbbá a felnőtt kreativitásának (és szocioemocionális változásának) is forrását adják (Moore és Russ, 2008). Míg egy normál fejlődésű, avagy egészséges személy mind a tárgyhasználat, mind pl. a mindennapi élethelyzetekben megnyilvánuló problémamegoldás kapcsán - az adott objekt konvencionális használatának felismerésén túl - sokrétű felhasználási/megoldási lehetőséget észlel, addig ez korántsem ilyen nyilvánvaló egy pl. autizmusspektrum- zavarral (Williams, Costall és Reddy, 1999), avagy szemantikus emlékezeti zavarral küzdő ember számára. Noha utóbbi esetben a készségszintü (implicit) tanulás/emlékezet kompenzáló hatással bírhat (Silveri és Ciccarelli, 2009). Ennek tükrében pedig különös jelentőséget nyerhet az ember kreativitásának feltárása, s az annak alakulását befolyásoló tényezőkkel való foglalkozás. Hasonlóképpen fontos lenne a pedagógia munkában is figyelmet szentelni a fiatalok ilyen irányú fejlesztésének, miként a tanárképzésben hangsúlyt kellene fektetni annak módszertanára, hogy a leendő oktatók-nevelők miként aknázhatják ki az iskolai életben adódó, a kreativitásnak teret engedő lehetőségeket (Starko, 2014). 


\section{Kreatív tárgyhasználat és a cselekvés kontextusa}

A tárgyhasználat társadalmi keretbe ágyazottságának és kapcsolatrendszerének, valamint az abban rejlő kreatív megnyilvánulásnak a szemléltetésére szolgál Sándor (2011) vizuális kommunikációs viszonyrendszerre alkotott modelljének a következőben átdolgozott változata, amelyen:

- egyfelől a tárgyat alkotó/létrehozó és tárgyhasználó/befogadó ember szempontjából a tárggyal való kapcsolat,

- másfelől az utóbbi személy által észlelt tárgy(mag) interpretációjának folyamata kerülnek bemutatásra (5. ábra).

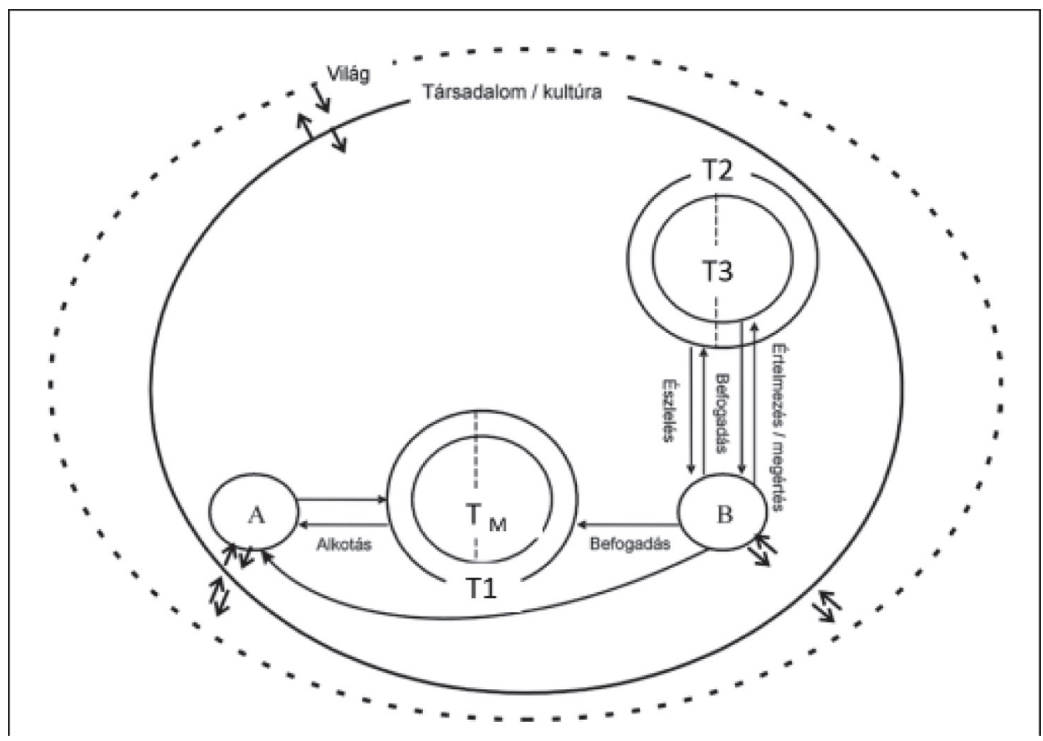

5. ábra. A társadalmi keretben zajló tárgyhasználat kapcsolatrendszere

[az ábra átdolgozott változat, eredetije a vizuális kommunikációra vonatkozik: Sándor, 2011, 33. o.; A és B - EGY TARSADALMI SZERVEZÖDÉS KÉTFÉLE SZEREPE: mint tárgyat alkotó/létrehozó és mint tárgyhasználó/befogadó

A-TÁRGYAT ALKOTÓ/LÉTREHOZÓ SZEREP (perceptuális alkotó tevékenység)

B - TÁRGYHASZNÁLÓ/BEFOGADÓ SZEREP (perceptuális befogadó/értelmezö tevékenység) TM - TÁRGY - ,.MAG”

T1 - TÁRGY 1: az alkotói szándék szerinti (használatra készült) tárgy

T2 - TÁRGY 2: a befogadói szerepben látott (és minöségben észlelt) tárgy (észlelés szintje)

T3 - TÁRGY 3: a befogadói szerepben aktuálisan meglátott/megértett (valamilyen jelentéssel felruházott) tárgy (jelentésadás szintje)]

Eszerint egy adott tárgy születése és használatba vétele is környezetünk rendszerén belül zajlik, sajátos dinamikát követve. Miként az alkotó is figyelembe veszi az adott társadalom szükségleteit, igényeit objektjének megalkotása során (pl. egy-egy ruhadarab megtervezése kapcsán milyen divathullám/stílus vezérli a tervezőket a világpiacon, vagy egy-egy játékfigura megjelentetése előtt felmérni, mely rajzfilm szereplői a leginkább közkedveltek a kisgyermekek által, s mindebből adódóan várhatóan mely termékek lesznek ténylegesen eladhatóak a célközönség számára), úgy a befogadóban létrejövő értelmezésnek is hasonló elemek adják kereteit (lásd csinos legyen az adott ruhadarab, vagy aranyos, a mesehősre valóban emlékeztető az adott karakterfigura, miként kedvező áron is szeretnénk hozzájutni mindezekhez). „Az alkotó és a befogadó tevékenysége (személy 
esetén: gondolkodásmódja) a folyamat közben is formálódik, az oda-vissza hatás kétirányú" (Sándor, 2011, 34. o.). Ha nem kompatibilis a kereslet és a kínálat, avagy változó társadalmi/egyéb szükségletek vagy igények támadnak a felhasználókban, úgy a tárgyakat létrehozók is változásokat kell eszközöljenek (pl. új terméket fognak a piacra dobni).

Az alkotói munka végére testet ölt az anyag, és a tárgy elkészül, miként a befogadó is számos lehetséges értelmezésből választva közelít azután a „mü”-höz. Meglehet, hogy valamely tárgy vizuálisan úgymond nyitottabb végü, és így kevésbé rajzolódik ki szemlélője tekintete előtt annak lényege, míg más darabok világosabb (konvencionálisabb) formát öltve, nyilvánvalóbb üzenetet hordoznak felhasználhatóságukra nézve. „A befogadó üzenetértelmezése a folyamatban és tevékenység közepette születik meg, tehát nem egy lineáris lépéssor végpontjaként. Az értelmezett üzenet részben találkozik az alkotói szándékkal, részben a befogadó felkészültsége és egyénisége alapján sajátos vonatkozásokkal bír" (Sándor, 2011, 34. o.). A dinamika az egész interpretációs kontextust áthatja, befolyásolja. Az ember párhuzamosan van jelen társas lényként és ágensként a rendszerben. „Végezetül: mindezek társadalmi kontextusukban, még tágabban pedig a világgal és világról alkotott képpel kölcsönös összefüggésben zajlanak" (Sándor, 2011, 34. o.).

\section{A „mintha játék” mint perceptuális alapú tevékenység}

„A játék önmagáért való. Az élmény örömét nem a szükségleti kielégülés adja, hanem maga a funkció, a ténykedés, a fantázia (Erdei, 2005). A gyermek „,mintha játéka” kifinomult kognitív tevékenységnek hat, mely három tevékenységet ölel fel: (1) egy adott tárgyat egyidejüleg két dolognak tekinteni, (2) azt képzelni, hogy egy objektum valamely más tárgy képviselője, (3) mentális reprezentációk feltételezése. Szokolszky (2006) szerint a gyermek azon szándéka, hogy észlelje a tárgy által felkínált témát, vezeti őt abban, hogy funkcionálisan a valós objektum helyett használja fel azt. S hogy mi határozza meg a gyermeki érdeklődés funkcionális jellemzőit? A színlelt cselekvés igénye az, ami determinálja a választást, noha meglehet, hogy időközben a gyermek módosítja az eredetileg kiválasztott tárggyal kapcsolatos szándékait, aminek révén új tárgyak is bevonásra kerülhetnek a cselekvésbe aszerint, hogy azok mennyire lennének úgymond jó tárgyak a tervezett tevékenységre. Ha pedig az így kiválasztásra került objekt funkciójában kellőképp illeszkedik a színlelt tevékenységhez, úgy ez a gyermek számára még örvendetesebb, mint ha azt a valós tárggyal hajthatná végre.

A tárgy „mintha játékban” való szerepének, funkciójának módosulását és kiválasztását tekintve Szokolszky (2006) az alábbi két kritériumot említi:

1. hasonlóság lásd objekt fizikai tulajdonságai nyomán,

2. korábbi tapasztalat, élmény a tárggyal eljátszani kívánt helyzetről.

A szimbolikus tárgy beépül a cselekvésbe, mint a céltárgy (valós tárgy) részleges megtestesülése, ami a „mintha játékot” támogatja (Szokolszky, 2006). Ezen megközelítés értelmében a „mintha játék” perceptuális alapú tevékenység, ami magában foglalja egyfelől a játékban részt vevő személy érzéseit, másfelől pedig a tárgy funkcionálisan releváns tulajdonságait (affordancia). Ezzel pedig Gibsonnak (1986) az affordanciákra mint egy konkrét személy cselekvési lehetőségeire épülő gondolatmenetét vezeti át a gyermek kreatív játékára, lásd azt a tárgyi világgal végzett alapfokú, online koordinációként láttatva.

Bármely tárgyhoz nagyszámú - előre meg nem határozható - cselekvési lehetőség kapcsolódhat, melyek a játékos és maga a helyzet függvényében választódnak ki (Szokolszky, 2006). A mindennapi életben is számos alkalommal és nagy rutinnal vagyunk képesek tárgyakat azok eredeti szerepétől eltérő módon alkalmazni. A nem konvencionális tárgyhasználat bár annak kulturális meghatározottságától elszakad, az affordanciák 
használatát megörzi. Tomasello (1999) elöször a tárgyak eredeti minőségben való használatát javasolja, melynek során annak föbb jellemzőit megtapasztalhatja a gyermek. Ezt követően, a „mintha tárgy” ún. szándékos affordanciái attól elkülöníthetővé lesznek, s így az immár „nem megfelelővé” vált tárgy játékos, szimbolikus használata válik lehetővé (Szokolszky, 2006). Szokolszky (2006) alapvetően egyetért Tomasello (1999) megközelítésével, mégis inkább javasolja a „mintha játéknak” a rendelkezésre álló affordanciák felőli értelmezését. Hiszen az aktuálisan elérhető és végül a céltárggyal kapcsolatban használatba vont affordanciák terén bizonyosan megragadható olyan mértékü különbség, ami differenciálhatja a felhasználási lehetőségek széles körét, miáltal a tárgy meghatározott és szimbolikus alkalmazása immár nem jelent komolyabb problémát a gyermek számára, hiszen alapvetően tudatában van annak tényleges használatával (Szokolszky, 2006).

\section{Kutatási kérdéseim, hipotéziseim}

\section{Kutatási kérdéseim}

1. Hogyan alakul az óvodás és a kisiskolás gyermekek tárgyválasztása, ha számukra ismeretlen és konvencionális objekteket kínálunk fel?

2. A tárgyválasztásban megnyilvánulnak-e nemi különbségek?

3. A statikus- (képek) és dinamikus (videók) ingeranyag-befolyással vannak-e a tárgyhasználat módjára?

4. Mennyiben befolyásolja a gyermek kreativitása a tárgyválasztást?

\section{Hipotéziseim}

H1: A kisiskolás gyermekeknél összességében magasabb arányban képviselt a konvencionális tárgyak választása, mint az óvodás korosztálynál.

H2: Az ismerős tárgyaknál lesznek „fiús” és „lányos” tárgyak.

H3: A dinamikus (ezért valósághoz közelibb) felvételek kreatívabb tárgyhasználatra motiválnak.

H4: A kreatívabb gyermekeknél gyakoribb az ismeretlen tárgyak választása és az objektekben rejlő sokoldalú felhasználási lehetőségek kiaknázása.

\section{A kutatásról}

\section{Résztvevök}

A vizsgálatban 15-15 óvodáskorú (életkor: 3-7 év, M: 4,867, SD: 1,407, 7 lány/8 fiú) és kisiskolás gyermek (életkor: 6-10 év, M: 8,133, SD: 1,187, 8 lány/7 fiú) vett részt. Valamennyien hazai nagyvárosokban (Budapest, Kecskemét, Miskolc, Pécs és Szeged), családi környezetben nevelkednek, szocioökonómiai státuszukat illetően jelentős különbség nem került feltárásra.

\section{Módszerek}

A vizsgálat során három szett keretében történt ingerbemutatás a gyermekek számára. Az első szettben az ingeranyagot különböző tárgyakról készült statikus felvételek (képek), illetve maguk a tárgyak szolgáltatták (6. ábra). A demonstrált 12 tárgy között 6 „furcsa” 
(a tárgy a gyermek számára nem ismert, annak fizikai jellemzői nem egyértelmüsítik azon funkciót, aminek a betöltésére készítették; nem reprezentánsa bármilyen létező/ elgondolt dolognak) és 6 „konvencionális” (a tárgy a gyermek számára ismert lehet, annak fizikai jellemzői egyértelmüsítik azon funkciót, aminek a betöltésére készítették, lásd valamely létező/elgondolt tárgy vagy élőlény reprezentánsa) játéktárgy szerepelt. A gyermekeknél sorsolással lett eldöntve, hogy elöször milyen formában találkoznak az objektekkel (fénykép/valós tárgy). A kétféle ingerbemutatással való indítás 1:1-hez arányban szerepelt. A képekkel folytatott munka során nem volt időkorlát, a tárgyi játék esetében 15 perc állt a gyermekek rendelkezésére.

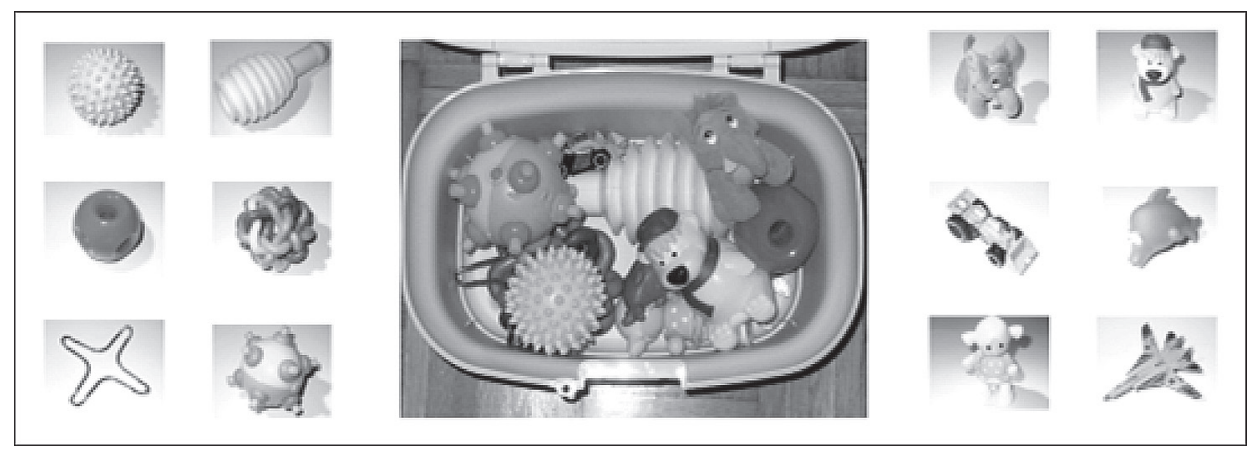

6. ábra. Az elsö szett

- Statikus ingeranyag (tárgyakról készült fényképek, $12 \mathrm{db}$ )

Instrukció -1: „Ezeken a kártyákon különböző tárgyakat látsz. Nézd meg őket jól, majd válaszd ki annak a hat dolognak a képét, amikkel a legszívesebben játszanál!’ Az adatlapon a rámutatás sorrendjében történt meg az egyes kártyák számozása.

Instrukció - 2: „Most rendezd sorba a kiválasztott hat képet aszerint, hogy a rajtuk lévő tárggyal mennyire szívesen játszanál! Balról, az első helyen legyen az a kártya, amelyik azt a tárgyat ábrázolja, amit először kézbe vennél, majd utána, a második helyen az a kártya, amelyik azt a tárgyat ábrázolja, amelyiket másodjára néznél meg, stb. A sor végén, jobb oldalt, az a tárgy legyen, amivel bár szívesen játszanál, de utoljára foglalkoznál vele.” A hat kártya kiválasztását követően tehát a gyermeknek az volt a feladata, hogy sorba rendezze azokat, prioritás szerint.

- Valós tárgyak $(12 \mathrm{db})$

Instrukció: „Ez itt egy varázsdoboz. Benne érdekes tárgyakat hoztam neked. Most odaadom a varázsdobozt, és játszhatsz ezekkel a dolgokkal.” Itt a tárgyválasztás sorrendje és az adott objekttel foglalkozás - másodpercben kifejezett - időtartama egyaránt rögzítésre kerültek.

A második szett alkalmával 6 dinamikus felvételen (videók) került demonstrálásra bizonyos tárgyak konvencionális és nem konvencionális (kreatív módon, „mintha tárgyként” történő) használata (7. ábra). 


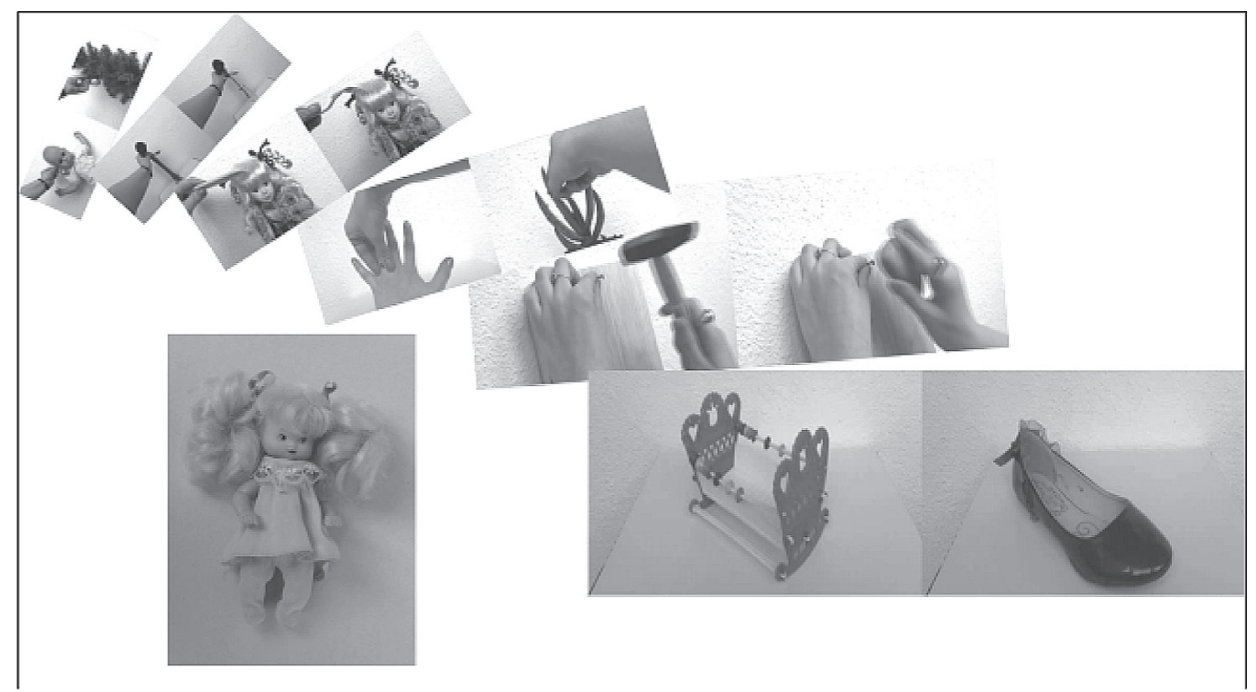

7. ábra. A 2. szett

A videofelvételek megtekintését követően a következő instrukció hangzott el a gyermek felé: „Hová tennéd ezt a dolgot (a kártyát a gyerek elé tesszük)? Mutass rá a két kép közül!" Az adatlapon pedig a két lehetséges tárgy melletti mezőben X-szel került jelölésre a gyermek válasza (pl. a babát a bölcsőbe/cipőbe tenni, a baba haját fésűvel/villával megigazítani).

A harmadik szett keretében pedig a gyermeknek azt kellett megmutatnia és elmondania, hogy milyen felhasználási lehetőségeket lát egy fakanálban (8. ábra).

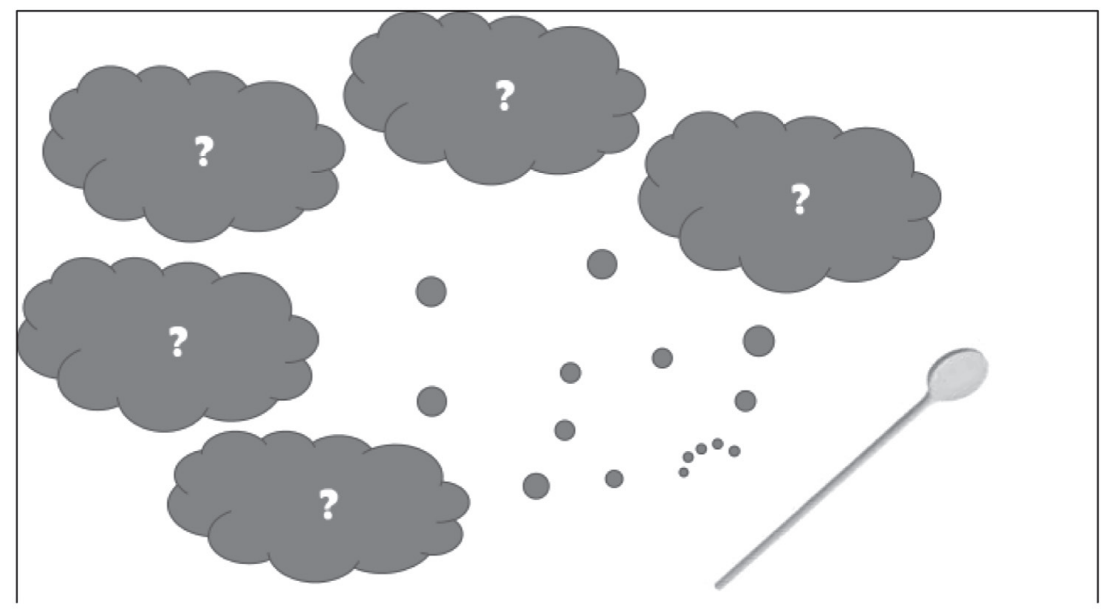

8. ábra. A 3. szett

A gyermek a következő instrukcióval kapta kezébe a fakanalat: „Mutasd meg, hogy mit lehet csinálni ezzel a fakanállal! Szavakkal is próbáld megfogalmazni a végzett cselekvést!" A demonstrált magatartás és verbalizált tevékenység egyaránt rögzítésre kerültek 

kenyeret/narancsot, képkeretnek használni). Ugyanitt később az egyes cselekvéseket felölelő kategóriák, melyekből ún. kreativitás pontszám volt kinyerhető, is dokumentálásra kerültek.

\section{Eljárás}

A tesztfelvételre a kutatásba vont gyermekek családjainál, diádikus helyzetben került sor. A vizsgálatba bevont felek készségesek és együttmüködőek voltak, zavaró körülmény nem merült fel. A gyermekek viselkedéses és verbális reakciói mindhárom szettnél külön a jelen vizsgálathoz készített adatlapokon lettek rögzítve (9. ábra).

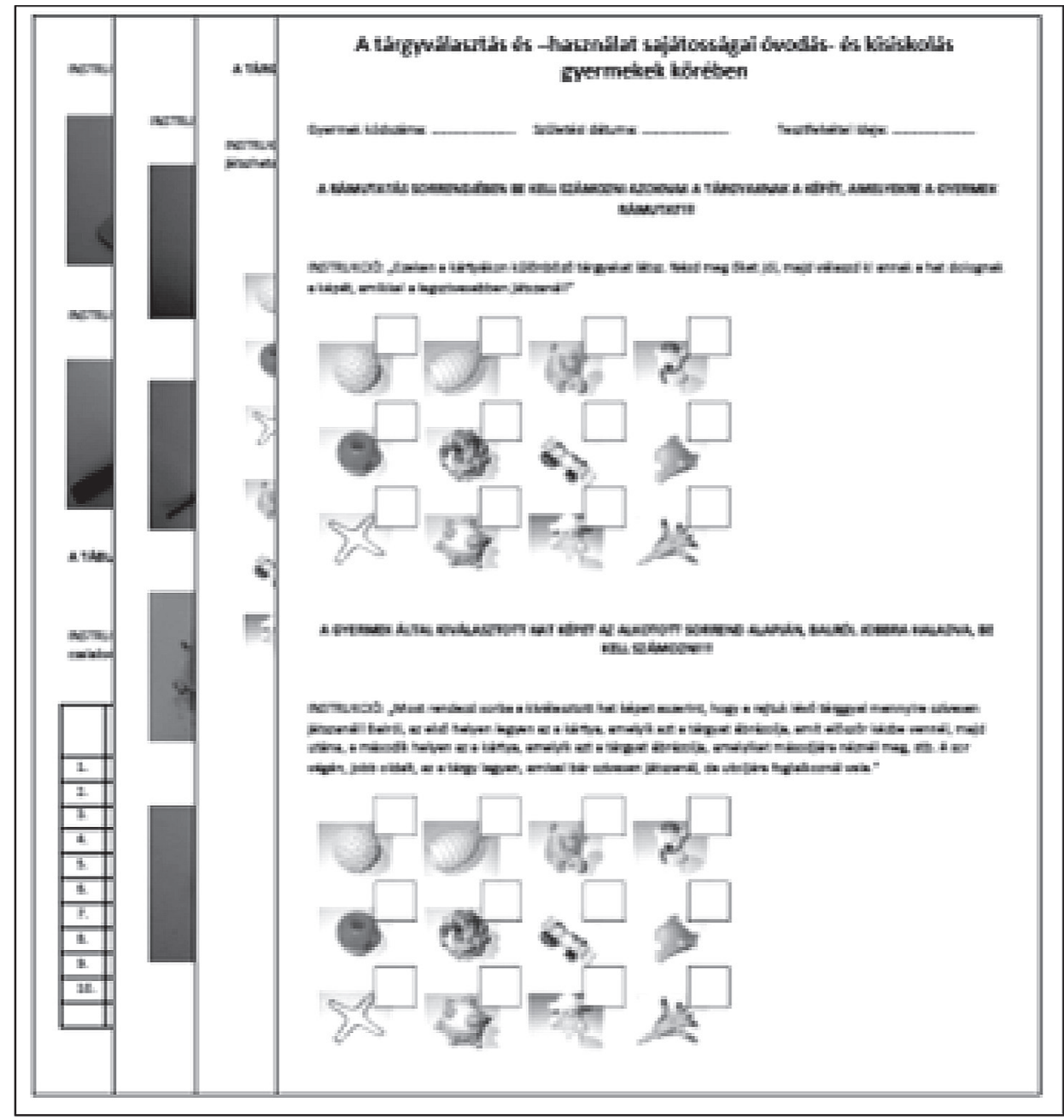

9. ábra. Adatfelvételi lapok 


\section{Eredmények}

Annak tekintetében, hogy a kártyán ábrázolt vagy a ténylegesen felkínált objekt volt-e az ingeranyag, nem mutatkozott eltérés a tárgyválasztást illetően. Életkori és nemi különbségek azonban egyaránt igazolódtak. Az óvodás és kisiskolás gyermekek is hajlamosabbak voltak olyan tárgyakat választani játékukhoz, amelyek egyértelmü jelentést hordoztak (konvencionális tárgyak). Mindazonáltal a kisebb gyermekek (óvodások) esetében - bár az eltérés statisztikailag nem volt szignifikáns - a furcsa tárgyak iránti érdeklődés kifejezettebbnek bizonyult (10. ábra).

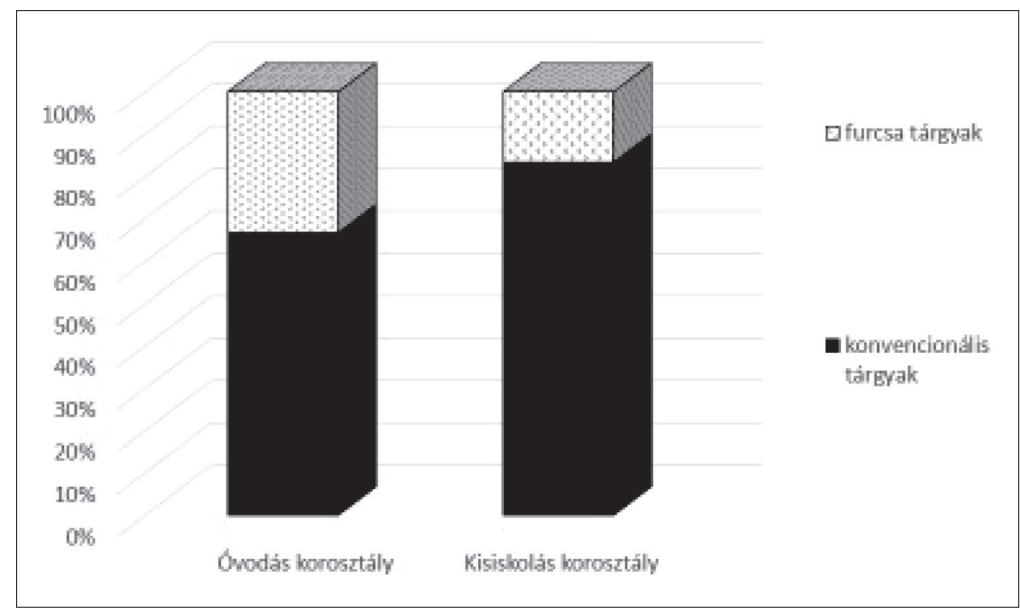

10. ábra. Tárgyválasztási preferencia óvodásoknál és kisiskolásoknál (N) (a diagram a valós tárgyak során tapasztalt tárgyválasztási adatok nyomán készült)

A tárgyhasználat 15 perces időtartama alatt is a konvencionális tárgyak voltak népszerübbek a gyermekcsoportok számára. Ezekkel az objektekkel szignifikánsan hosszabb időtartamban játszottak a kisiskolások, mint a fiatalabbak $[\mathrm{t}(28)=-2,449, \mathrm{p}=0,021]$. A furcsa tárgyak pedig szignifikánsan hosszabb ideig kötötték le az óvodások figyelmét, mint ezt a másik almintán tapasztalni lehetett $[\mathrm{t}(28)=2,449, \mathrm{p}=0,021]$ (11. ábra).

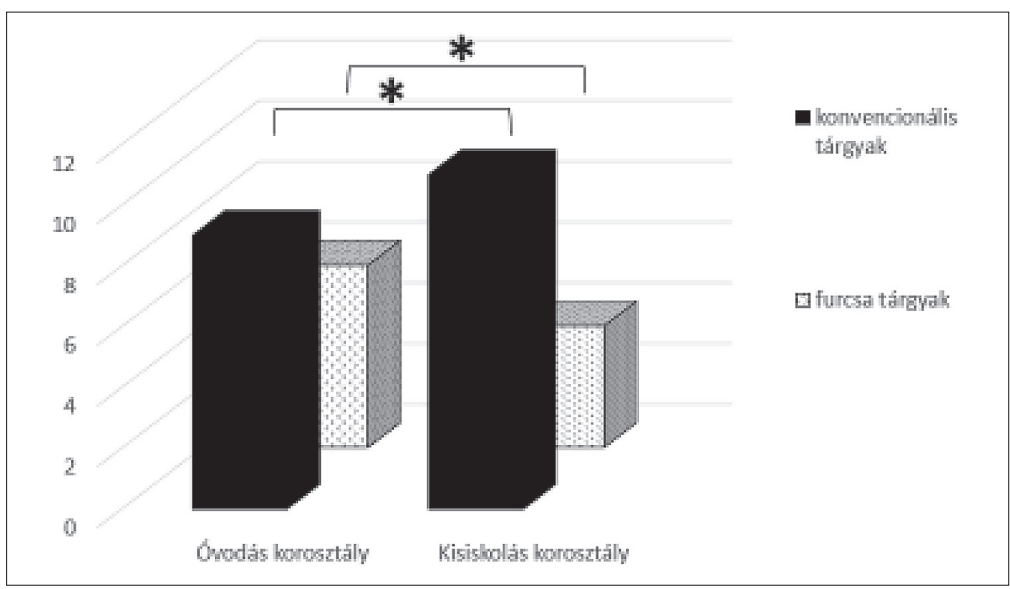

11. ábra. Tárgyhasználati preferencia óvodásoknál és kiskolásoknál (T) 
Noha mindkét nem képviselői szívesebben választottak konvencionális tárgyakat, a lányok azokból is az élőlény reprezentánsokat (baba, maci, kiselefánt, delfin), míg a fiúk a jármüveket (autó, repülőgép) részesítették előnyben. Továbbá a fiúknál inkább fordult elö olyan objektek játékba vonása, amelyek funkciója nem volt rögtön egyértelmüsíthető lásd furcsa tárgyak. Ezeket a gyermekek kreatív módon, változatos cselekvéseken keresztül mintegy tesztelték és vonták használatba (pl. a kis pumpát dobverőként, telefonkagylóként, mézcsepegtető eszközként szerepeltették, a tüsi labda pedig éppen úgy szerepelt masszírozó eszközként, mint fagyi gombóc vagy „feldühödött gömbhal” reprezentánsként). A lányok körében kevesebb, a fiúknál pedig több favorizált tárgy volt (12. ábra).

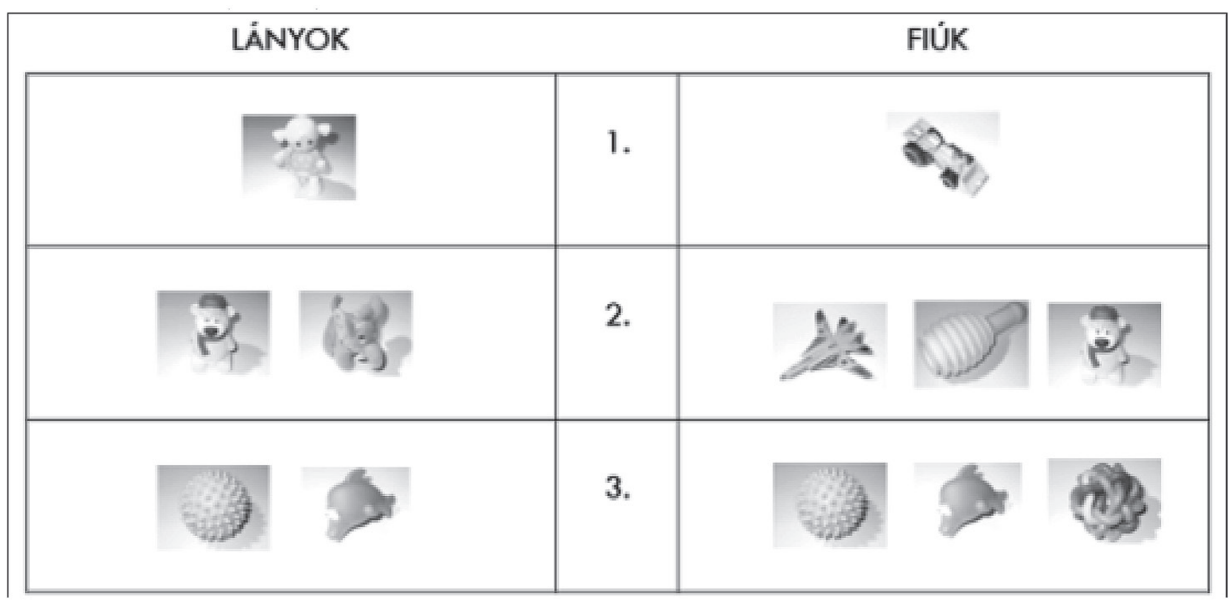

12. ábra Nemi különbségek a tárgyválasztás, illetve -használat vonatkozásában

A dinamikus ingeranyagnál (videofelvételek) a korábbiakhoz hasonló arányban - szignifikáns különbséget nem adva a korcsoportok között - volt tapasztalható a konvencionális, illetve furcsa tárgyakra eső választások megjelenése. A kreatívabb gyermekeknél azonban verbális síkon többször jelent meg a videofelvételen demonstrált nem konvencionális tárgyhasználat (pl. cipőbe tenni a babát, hogy pihenjen, vagy villával megfésülni a baba haját, hogy ne legyen kócos), míg a többiek legfeljebb annak helytelenségéről szóltak.

A két vizsgált korosztály tekintetében közel azonos kreativitás-pontszám mutatkozott (13. ábra), noha a kisebb gyermekek az utolsó szett alkalmával több felhasználási lehetőséget tudtak említeni a fakanál kapcsán (vagyis egy adott kategórián belül a tárgyhasználatra nézve számos opciót soroltak fel, pl. a fakanállal meg lehet kavarni a levest/ fözeléket/ételt).

A kreatívabb (magasabb kreativitás pontszámú) gyermekeknél inkább esett a tárgyi játék alkalmával a választás furcsa tárgyra $[\mathrm{r}(28)=0,583, \mathrm{p}=0,001]$, miként azokkal hosszabb időtartamban is végeztek ezek a gyermekek cselekvést $[\mathrm{r}(28)=0,735, \mathrm{p}=$ $0,000]$. A konvencionális tárgyak választása $[\mathrm{r}(28)=-0,583, \mathrm{p}=0,001]$ és használata $[\mathrm{r}(28)=-0,735, \mathrm{p}=0,000]$ pedig negatív irányú összefüggést mutatott a kreativitásnál rögzített méröszámmal. 


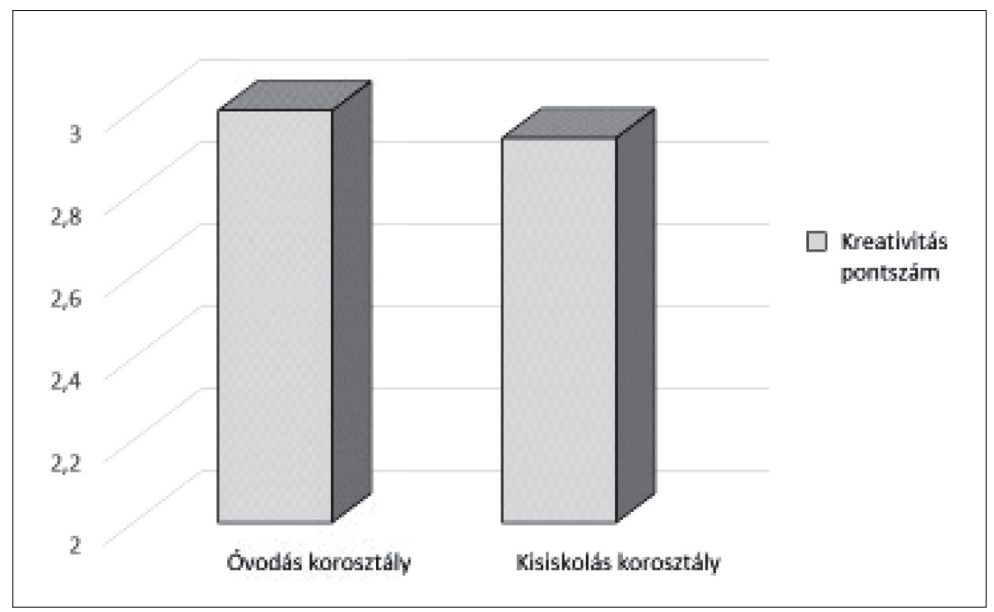

13. ábra. A kreativitás pontszámok alakulása a két alminta relációjában

\section{Összegzés, konklúzió}

Vizsgálatomban óvodás és kisiskolás gyermekek tárgyválasztását és -használatát hasonlítottam össze, különös tekintettel a kreatív megnyilvánulásokra. Ezeknek a korosztálybeli sajátosságoknak a megismerése ugyanis segítséget nyújthat a normál fejlödéssel járó tárgyi manipuláció, illetve cselekvésformák alakulásának jobb megismerésére, valamint ennek referenciaként való alkalmazására olyan személyek esetében, akiknél tárgyhasználati nehézségek, illetve zavarok mutatkoznak.

Eszerint mindkét tekintett korosztály előnyben részesítette a konvencionális tárgyakat a játék során, a fantázia számára tágabb teret engedő furcsa tárgyak választása és -használata pedig inkább a kisebb gyermekeknél jelent meg. Első hipotézisem tehát - Wohlgelernter, Diesendruck és Markson (2010) a felnövekvő gyermekek világról és az abban létező dolgok konvencionális természetéről szerzett és bővülő ismereteinek alakulására vonatkozó kutatása alkalmával nyert eredményeivel összhangban - igazolást nyert.

A felkínált objektekre vonatkozó preferenciát illetően nemi különbségek is feltárásra kerültek. A lányok inkább humánvagy állatfigurákat vontak be játékukba, míg a fiúk közlekedési eszközök reprezentánsait választották és használták szíveseb-

... a dinamikus ingeranyag mely a valóság hitelesebb leképezését nyújtja - kreativabb gondolkodást eredményez, és inkább motivál ilyen jellegú tárgyválasztásra egy-egy adott cselekvésre vonatkozóan, nem nyert igazolást. Figyelemre méltó, hogy verbális síkon több gyermek is bár felvetette a nem konvencionális tárgyhasználat lehetôségét, a válaszadás alkalmával mégis az évek során elsajátított konvencionális tárgyhasználatról adtak tanúbizonyságot. Ez pedig a felnövekvó gyermek tanulási folyamatáról vall, alátámasztva a tárgyhasználat szocializációs keretbe ágyazottságát. 
ben. A lányoknál szükebb spektrumon mozgott a különösen kedvelt tárgyak köre (1. helyen konvencionális tárgy állt, lásd baba), a fiúknál (1. helyen konvencionális tárgy állt, lásd autó) pedig nagyobb arányú volt a sokoldalú felhasználási lehetőséget rejtő, akár furcsa tárgyak (lásd kis fehér pumpa, szokatlan formájú labdák) iránti érdeklődés. Vagyis - Kósa (2005) a gyermeki játéknál, a várható, nemi identitáshoz is kapcsolódó, szerepeket illető gyakorlásnál leírt gondolataihoz jól illeszkedve - második hipotézisem is igaznak bizonyult.

Harmadik hipotézisem, miszerint a dinamikus ingeranyag - mely a valóság hitelesebb leképezését nyújtja - kreatívabb gondolkodást eredményez, és inkább motivál ilyen jellegü tárgyválasztásra egy-egy adott cselekvésre vonatkozóan, nem nyert igazolást. Figyelemre méltó, hogy verbális síkon több gyermek is bár felvetette a nem konvencionális tárgyhasználat lehetőségét, a válaszadás alkalmával mégis az évek során elsajátított konvencionális tárgyhasználatról adtak tanúbizonyságot. Ez pedig a felnövekvő gyermek tanulási folyamatáról vall, alátámasztva a tárgyhasználat szocializációs keretbe ágyazottságát. Mindazonáltal a válaszadásban a megfelelési igény is bizonyára megnyilvánult. Érdemes lenne a későbbiekben a most videón demonstrált cselekvéseknél használt eszközöket ténylegesen is a gyermek rendelkezésére bocsátva megismételni a tesztfelvételt, miáltal a gyermekek a mostani döntéshozatali helyzetben (kártyára mutatás) talán erőteljesebben müködő kontrollt elengedve szabad játékban próbálhatnák ki a videón demonstrált, megfigyelt tárgyhasználati helyzeteket (noha az első szett kapcsán valójában nem mutatkozott eltérés a kártyákon avagy tényleges elérhető objekteken keresztül történt tárgyhasználati helyzetre vonatkozó eszközválasztásban).

Utolsó, negyedik hipotézisemmel összefüggésben a magasabb kreativitás pontszámot elért gyermekek valóban nyitottabbnak bizonyultak a különösebb formával bíró tárgyak választására és használatba vételére. Elgondolkodtató - noha alacsony elemszámú minta állt rendelkezésre, és a különbség mindössze csekély mértékü volt -, hogy az óvodás gyermekek némileg magasabb fokú kreativitásról adtak számot, lásd kategória alapú pontozás, mint pár évvel idősebb, kisiskolás társaik. Amennyiben pedig az adott szettben felkínált eszköz (fakanál) kapcsán gyermekek által felsorolt tárgyhasználati lehetőségeket tekintjük, úgy markánsabb eltérést is találunk az alminták viszonylatában.

Azonban nem hagyhatjuk figyelmen kívül a tényt, hogy a klaszterezés (csoportosítás) révén kapott számszerü adat nem csupán a gyermeknél mérni kívánt kreativitás, de az emlékezet és szervezési képesség mutatójaként is áll. Hiszen „a kategorizáció, mint mentális müködés, kritikus szerepet játszik a megismerés megszervezésében és stabilitásában” (Rokszin, 2013, 38. o.). „Mind a csoportosítás, mind pedig a váltás utal arra, hogy melyek az alany szemantikus teljesítményének jellemzői. A váltási folyamat magába foglalja a különböző szemantikus vagy fonemikus alkategóriák keresését és elöhívását, míg a csoportosítási folyamat alatt a példák keresését és előhívását értjük ugyanabból az alkategóriából... a szemantikus és végrehajtó képességek ugyanúgy fontosak a szemantikus fluenciában" (Tánczos, 2012, 42-43. o.). A végrehajtó funkció komponenseinek (váltás, tervezés, monitorozás, gátlás/kontroll, flexibilitás) fejlődése pedig komoly életkori különbségekkel bír, melyek közül a „váltás” megjelenése 3-5 éves korra tehető (lásd óvodáskor), s teljesítménynövekedést 7-9 éves kortól a serdülőkorig mutat (lásd iskoláskor) (Tánczos, 2014). Vagyis éppen a tekintett két korcsoportnál van egy jelentős fordulópont a nevezett, kreativitás pontszámra minden bizonnyal hatást gyakorló, de legalábbis összefüggő komponens fejlődésében.

Miben összegezhetjük tehát az eredmények jelentőségét? A kisgyermekkori élmények hatása meghatározó a későbbiekre nézve (Fáyné Dombi, 2010). Az egészséges gyermek optimális fejlődéséhez megfelelő környezetre van szükség. Hiszen a cselekvő gyermek információt gyüjt a körülvevő világról, miáltal bővíti ismereteit (Cole és Cole, 2006). Mindennapi tapasztalataink ezért komoly jelentőséggel bírnak. Hatásuk a társas 
interakciókban, játékban, motoros képességekben és nyelvi fejlődésben egyaránt megmutatkozik. A változatos környezet a gyermek játékának színvonalára is kedvező hatást gyakorol (Ward, 1969). A tárgy használatának szélesebb körü alkalmazása pedig tovább fokozza a gyermek tevékenységben való részvételi kedvét és maga kezdeményezte akcióit (Williams és Costall, 2000).

A szociális gondozók szerepe is fontos, akik jelenlétükkel és verbális-nonverbális megnyilvánulásaikkal hasonlóképpen befolyást gyakorolnak a gyermek (tárgyválasztási és -használati) magatartására (Williams és Costall, 2000). A mikrokörnyezet (család) és másodlagos szocializációnk helyszíneinek (óvoda, iskola) felnőtt tagjai modellként, viselkedésünk jutalmazással-büntetéssel és verbális instrukciókkal való formálóiként támogatják beilleszkedésünket társadalmunkba, kultúránkba. Ök azok, akik irányítják figyelmünket, személyiségünk egészére hatással vannak. Pozitív esetben pedig értékelik kreativitásunkat, ösztönöznek az eredeti gondolatokra, és jó néven veszik az ilyen jellegü megnyilatkozásainkat.

Végezetül, Logan és mtsai (2005) a korai tanulási és fejlődési folyamatok hátterében álló tényezőkre és azok viszonyrendszerére hívják fel a figyelmünket. Miként jegyzik, az én-indította cselekvés, tárgyakkal és emberekkel való interakció gyakran együttesen fordulnak elö, s azok bármelyikének fejlesztése a többi kategória vonatkozásában is szupportív hatást eredményezhet. A szerzők kiemelik, hogy a különböző zavarral élő gyermekekkel folytatott munka a normál fejlődéstől való elmaradásokra/eltérésekre kell, hogy orientáljon, megszüntetve a fennálló környezeti és kulturális akadályokat, és maximalizálva a cselekvéskor, játékban és interakciós térben megnyilvánuló azon viselkedésformákat, amelyek a hétköznapokban is nagy számban és gyakran elöfordulnak. A fejlesztő tevékenységre pedig - optimális esetben - a gyermek életének első két évében kell, hogy sor kerüljön, lásd a környezeti ingerekre agyunk ezen kritikus periódusban tud a leginkább érzékenyen és plasztikus módon reagálni. Ehhez azonban mind több információnak kell birtokában legyünk az egészséges gyermekek fejlődésére mint referenciakeretre vonatkozóan. A jövőbeli vizsgálatok során tehát a tárgyválasztási és -használati szokások mind változatosabb kontextusban, illetve elsősorban a gyermek számára mindennapi életteret jelentő helyzetekben történő vizsgálatára van szükség.

\section{Irodalomjegyzék}

Balogh Tibor (1991): Lélek és játék. Akadémiai Kiadó, Budapest

Bergen, D. (2002): The Role of Pretend Play in Children's Cognitive Development. Early Childhood. Research and Practice, 4. 1. sz. 1-8.

Bretherton, I. (1984): Symbolic Play: The Development of Social Understanding. Academic Press Inc. (London) Ltd., London, UK

Bronfenbrenner, U. (1977): Toward an Experimental Ecology of Human Development. American Psychologist, July, 513-531. DOI: 10.1037//0003066x.32.7.513

Brown, S. W., Renzulli, J. S., Gubbins, E. J., Siegle, D., Zhang, W. és Chen, C.-H. (2005): Assumptions Underlying the Identification of Gifted and Talented Students. Gifted Child Quarterly, 49. 1. sz. 68-79. DOI: $10.1177 / 001698620504900107$
Cole, M. és Cole, S. R. (2006): Fejlödéslélektan. Osiris Tankönyvkiadó, Budapest

Czeizel Endre (1997): Sors és tehetség. FITT Image and Minerva, Budapest

Elkonyin, D. B. (1964): Gyermeklélektan. Tankönyvkiadó, Budapest

Erdei Katalin (2005): A játék a pszichológia elméletében. In: Benkő Zsuzsanna (szerk.): Szemelvények a pszichológia témaköréböl. JGYF Kiadó, Szeged. 26-32.

Fáyné Dombi Alice (2010): A kisgyermekkori élmények hatása a gyermek fejlődésére. In: Dombi Alice és Soós Katalin (szerk.): Fejezetek a kisgyermeknevelés köréböl. APC Stúdió, Gyula, 81-85.

Fischer, B. J. és Specht, D. (1999): Successful Aging And Creativity In Later Life. Journal of Aging Studies, 13. 4. sz. 457-472. DOI: $10.1016 / \mathrm{s} 0890$ 4065(99)00021-3 
Fuchs, G. L., Kumar, V. K. és Porter, J. (2007): Emotional creativity, alexithymia, and styles of creativity. Creativity Research Journal, 19. 2-3. sz. 233-245. DOI: 10.1080/10400410701397313

Gibson, J. J. (1986): The Ecological Approach to Visual Perception. Psychology Press Taylor \& Francis Group, LLC, New York, NY. DOI: 10.4324/9780203767764

Hobson, J. A., Hobson, R. P., Malik, S., Bargiota, K. és Calo, S. (2012): The relation between social engagement and pretend play in autism. British Journal of Developmental Psychology, 31. 1. sz. 114-127. DOI: 10.1111/j.2044-835x.2012.02083.x

Hoffmann, J. és Russ, S. (2012): Pretend play, creativity, and emotion regulation in children. Psychology of Aesthetics, Creativity, and the Arts, 6. 2. sz. 175184. DOI: $10.1037 / \mathrm{a} 0026299$

Hunnius, S. és Bekkering, H. (2010): The Early Development of Object Knowledge: A Study of Infants' Visual Anticipations During Action Observation. Developmental Psychology, 46. 2. sz. 446-454. DOI: $10.1037 / \mathrm{a} 0016543$

Kékes Szabó Marietta és Szokolszky Ágnes (2013): Dyadic interaction and the development of object use in typical development and autism spectrum disorder. Practice and Theory in Systems of Education, 8. 4. sz. 365-388.

Kerr, B. (szerk., 2009): Encyclopedia of Giftedness, Creativity, and Talent. SAGE Publications, Inc., London, UK

Kósa Éva (2005): A szocializáció elméleti kérdései. In: Vajda Zsuzsanna és Kósa Éva (szerk.): Neveléslélektan. Osiris Kiadó, Budapest. 46-113.

Kőváry Zoltán (2015): Herman Ottó és a tudományos kreativitás személyes gyökerei. Előadás. Herman Ottó a polihisztor munkássága, hatása c. konferencia. Budapest, 2015. február 26-27.; https://www.youtube.com/watch? $=\mathrm{kgD} 5 \mathrm{wHpyb}-\mathrm{g}$ letöltve: 2016 . július 24 .

Lam, Y. G. és Yeung, S. S. (2012): Cognitive deficits and symbolic play in preschoolers with autism. Research in Autism Spectrum Disorders, 6. 1. sz. 560-564. DOI: 10.1016/j.rasd.2011.07.017

Lillard, A. S., Lerner, M. D., Hopkins, E. J., Dore, R. A., Smith, E. D. és Palmquist, C. M. (2013): The impact of pretend play on children's development: A review of the evidence. Psychological Bulletin, 139. 1. sz. 1-34.

Logan, S. W., Schreiber, M. S. M., Lobo, P. T. M., Pritchard. B. S. B., George, B. S. L. és Galloway, J. C. (2015): Real world behavioral performance: Physical activity, play, and object-related behaviors of toddlers with and without disabilities. Pediatric Physical Therapy, 27. 4. sz. 433-441.
Messinger, D. S. és Fogel, A. (2008): Give and Take: The Development of Conventional Infant Gestures. Merrill-Palmer Quarterly, 44. 4. sz. 566-590.

Moore, M. és Russ, S. W. (2008): „Follow-Up of a Pretend Play Intervention: Effects on Play, Creativity, and Emotional Processes in Children." Creativity Research Journal, 20. 427-436. DOI: 10.1080/10400410802391892

Pellegrini, A. D. (1980): The relationship between kindergartners' play and achievement in prereading, language, and writing. Psychology in the Schools, 17. 4. sz. 530-535. DOI: 10.1002/1520-6807 (198010)17:4<530::aid-pits2310170419>3.0.co;2-a

Pellegrini, A. D. (2016): Object Use in Childhood: Development and Possible Functions. In.: D. C. Geary és D. B. Berch (szerk.): Evolutionary Perspectives on Child Development and Education. Vol. 1.: Springer International Publishing, University of Minnesota/Twin Cities Campus, Minneapolis, MN, USA. 95-115. DOI: 10.1007/978-3-319-29986-0_4

Piaget, J. (1974): Need and Significance of Crosscultural Studies in Genetic Psychology. In: J. W. Berry és P. R. Dasen (szerk.): Culture and cognition: Reading in Cross-cultural Psychology. Metheun and Co Ltd., London, UK. 299-309.

Renzulli, J. S. (2002): Emerging Conceptions of Giftedness: Building a Bridge to the New Century. Exceptionality: A Special Education Journal, 10. 2. sz. 67-75. DOI: $10.1207 / \mathrm{s} 15327035 \mathrm{ex} 1002 \_2$

Rokszin Adrienn Aranka (2013): A vizuális kategorizációs folyamatok érésének feltérképezése 7-15 éves egészséges gyermekek és felnőttek körében. Iskolakultúra, 23. 10. sz. 37-51.

Rogers, S. J., Cook, I. és Meryl, A. (2005): Imitation and Play in Autism. In: Volkmar, F. R., Paul, R., Klin, A. és Cohen, D. (szerk.): Handbook of Autism and Pervasive Developmental Disorders. Diagnosis, Development, Neurobiology and Behavior. Volume One. Wiley \& Sons, Inc., Hoboken, New Jersey. 382-405. DOI: 10.1002/9780470939345.ch14

Russ, S. W. (1998): Play, creativity, and adaptive functioning: Implications for play interventions. Journal of Clinical Child Psychology, 27. 4. sz. 469-480. DOI: 10.1207/s15374424jccp2704_11

Russ, S. W. és Schafer, E. D. (2006): Affect in fantasy play, emotions in memories, and divergent thinking. Creativity Research Journal, 18. 3. sz. 347-345. DOI: 10.1207/s15326934crj1803_9

Sándor Zsuzsa (2011). Vizuális alkotástípusok a kommunikációban. A vizuális kommunikáció változatainak összehasonlitó elemzése c. disszertáció. PTE BTK Nyelvtudományi Doktori Iskola, Kommunikáció Doktori Program; http://nydi.btk.pte.hu/sites/ nydi.btk.pte.hu/files/doktori_vedesek/SandorZsuzsanna_2012_disszertacio.pdf letöltve: 2016. július 15. 
Silveri, M. C. és Ciccarelli, N. (2009): Semantic memory in object use. Neuropsychologia, 47. 2634 2641. DOI: 10.1016/j.neuropsychologia.2009.05.013

Stagnitti, K. és Unsworth, C. (2000): The Importance of Pretend Play in Child Development: An Occupational Therapy Perspective. British Journal of Occupational Therapy, 63. 3. sz. 121-127. DOI: $10.1177 / 030802260006300306$

Starko, A. J. (2014): Creativity in the Classroom: Schools of Curious Delight. Routledge, Taylor \& Francis Group, New York, NY. DOI: $10.4324 / 9780203115176$

Szokolszky, Á. (2006): Object Use in Pretend Play: Symbolic or Functional? In: Costall, A. és Dreier, A. (szerk.): Doing Things with Things. Design and Use of Ordinary Objects. Ashgate Publishing Group, London, England. 67-87. DOI: 10.4324/9781315577920

Tánczos Tímea (2012): A végrehajtó funkciók szerepe az iskolában és a verbálisfluencia-tesztek. Iskolakultúra, 22. 6. sz. 38-51.

Tánczos Tímea (2014): A verbális fluencia és munkamemória életkori változásai és szerepük az iskolai teljesitményben c. disszertáció. SZTE BTK Neveléstudományi Doktori Iskola, Pszichológia Doktori Program; http://doktori.bibl.u-szeged.hu/2197/1/ Disszertacio Tanczos.pdf letöltve: 2016. július 21 . DOI: $10.142 \overline{3} 2 /$ phd.2197

Tomasello, M. (1999): The Cultural Origins of Human Cognition. Harvard University Press, Cambridge, Massachusetts

Valsiner, J. (1987): Culture and the Develoment of Children's Action: A Cultural Historical Theory. Wiley, Chichester, UK

Vandenberg, B. (1981): The Role of Play in the Development of Insightful Tool-Using Strategies. Mer-
rill-Palmer Quarterly of Behavior and Development, 27. 2. sz. 97-109.

Ward, W. C. (1969): Creativity and environmental cues in nursery school children. Developmental Psychology, 1. 5. sz. 543-547. DOI: 10.1037/h0027977

Williams, E., és Costall, A. (2000): Taking things more seriously. Psychological theories of autism and the material-social devide. In: Graves-Brown, P. M. (szerk.): Matter, Materiality and Modern Culture. Routledge Taylor \& Francis Group, London, England. 97-111. DOI: 10.4324/9780203351635

Williams, E., Costall, A. és Reddy, V. (1999): Children with Autism Experience Problems with Both Objects and People. Journal of Autism and Developmental Disorders, 29. 5. sz. 368-378.

Williams, E. és Kendell-Scott, L. (2006): Autism and Object Use: The Mutualitiy of the Social and Material in Children's Developing Understanding and Use of Everyday Objects. In: Costall, A. és Dreier, A. (szerk.): Doing Things with Things. Design and Use of Ordinary Objects. Ashgate Publishing Group, London, UK. 51-66. DOI: 10.4324/9781315577920

Wohlgelernter, S., Diesendruck, G. és Markson, L. (2010): What Is a Conventional Object Function? The Effects of Intentionality and Consistency of Use. Journal of Cognition and Development, 11. 3. sz. 269-292. DOI: 10.1080/15248371003699985

Wright, C. és Diener, M. L. (2012): Play, Creativity, and Socioemotional Development: Weaving the Threads of Influence. In: Saracho, O. (szerk.): Contemporary Perspectives on Research in Creativity in Early Childhood Education. Information Age Publishing (IAP), Inc., Charlotte, North Carolina. 271-292. 